\title{
DÜBLIN
}

Technological University Dublin

ARROW@TU Dublin

\section{Identity reconstruction of Chinese migrant women in Ireland}

Jun $\mathrm{Ni}$

Technological University Dublin, jun.ni@TUDublin.ie

Follow this and additional works at: https://arrow.tudublin.ie/aaschsslbk

Part of the Migration Studies Commons, Place and Environment Commons, Race and Ethnicity Commons, and the Social Psychology and Interaction Commons

\section{Recommended Citation}

Ni J. (2020) Identity Reconstruction of Chinese Migrant Women in Ireland. In: Zhouxiang L. (eds) Chinese National Identity in the Age of Globalisation. Palgrave Macmillan, Singapore. DOI: 10.1007/

978-981-15-4538-2_17

This Book Chapter is brought to you for free and open access by the Social Sciences at ARROW@TU Dublin. It has been accepted for inclusion in Books/Book chapters by an authorized administrator of ARROW@TU Dublin.

For more information, please contact arrow.admin@tudublin.ie, aisling.coyne@tudublin.ie, gerard.connolly@tudublin.ie.

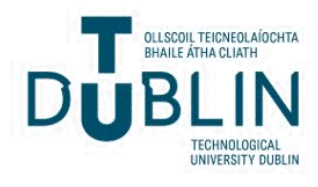




\title{
Identity Reconstruction of Chinese Migrant Women in Ireland
}

Jun Ni

\begin{abstract}
This paper presents an original qualitative study on the cross-cultural adaptation process and identity reconstruction of Chinese migrant women in Ireland. Using a thematic analysis approach, twelve in-depth qualitative interviews were conducted with Chinese migrant women. Linking contemporary sociocultural identity theories with practice, the relationship between language, cultural learning and identity reconstruction are examined through exploring the actual experiences of Chinese migrant women living in Ireland. Based on an analysis of Chinese women's cross-cultural adaptation experience in Ireland, this study identifies facilitators of and barriers to the cross-cultural adaptation. The current study found that the women who adopted an integrated strategy developed an intercultural identity. On the one hand, they want to maintain their Chinese cultural identity and heritage, at the same time they are committed to developing relationships with Irish mainstream society. Most Chinese women take pride in their Chinese culture and values. Pride in Chinese culture results in higher levels of self-esteem. They aim to bring their own culture to the attention of Irish people and feel proud of playing the role of an intercultural ambassador.
\end{abstract}

Keywords: migration, cross-cultural adaptation, identity reconstruction 


\section{Introduction}

When migrants move from their country of origin to a different country, they meet unfamiliar behavior, symbols, rules, roles, beliefs and values. It is a challenge for migrants to deal with two cultures simultaneously because the home culture and the host culture are both exerting pressure to conform. Thus this often leads to changes in a person's sense of self and identity. Migrants face the dilemma of cross-cultural adaptation and identity maintenance. Scholars in the field of intercultural studies have discussed the changing identities that include both the home and host culture and that result from cross-cultural contact. Kim points out that hybridization of identity emerges from the simultaneous engagement in both the home culture and the host culture, which resembles the development of a larger intercultural identity as a result of engaging in the process of cross-cultural adaptation. ${ }^{1}$ The current study, therefore, is a response to this call and an attempt to examine the relationship between cross-cultural adaptation and identity reconstruction in an empirical study of the cross-cultural adjustment process of Chinese migrant women in Ireland. Using a thematic analysis approach, in-depth face-to-face interviews were conducted with twelve Chinese women.

It is necessary to introduce the background of migration in Ireland and migration history of Chinese in Ireland. Ireland has traditionally been a country of emigration, particularly to Great Britain, the United States and Australia. ${ }^{2}$ Following the economic boom of the Celtic Tiger in the mid-1990s, Ireland was considered a country of immigration, with a culturally diverse society being the result of this. ${ }^{3}$ The 2006 Census showed that around 10 percent of residents in Ireland were of foreign nationality. ${ }^{4}$ Net migration to Ireland increased from 8,000 in 1996 to over 420,000 in 2006 . Non-EU migrants dominated the migration flows between 2001 and 2004. Among the various categories of non-EU nationals coming to Ireland in the last decade, the great majority have been workers (about 280,000 work permits were issued between 1998 
and 2008), followed by asylum seekers (74,000 applications made from1998 to 2008), students and dependents. ${ }^{5}$ Chinese migrants are one of the largest minority ethnic groups in Ireland.

There are two main waves of Chinese migration into Ireland. The first wave of migration came mostly from Hong Kong. Long before the Celtic Tiger days, in the late 1950s and early 1960s, earlier Chinese migrants, mostly originating from Hong Kong, moved to the Republic of Ireland from Northern Ireland and the UK. Members of the first wave tend to run their own businesses, mostly in the food and catering sector, and most have settled permanently in Ireland. ${ }^{6}$ The second wave of migration to Ireland began in the late 1990 s and mostly were students who came from the People's Republic of China. ${ }^{7}$ The population of Chinese migrants increased significantly between 2002 and 2006. Statistically, 11,161 Chinese people were living in Ireland in April 2006 - an increase of 91 per cent on the 2002 figure of 5,842. ${ }^{8}$ However, there is widespread agreement that in fact there are more Chinese immigrants than this figure reveals in Ireland. Other estimates, based on PPS numbers, work permit and visa data, residency figures and other indicators, show the top 3 foreign national groupings in 2006 residing in Ireland as: Poland, 150,000; China, 60,000; Lithuania, 45,000. ${ }^{9}$ Given the large number of Chinese immigrants living in Ireland and the increasing benefits of trade with China, there is a great opportunity for exploratory research on cultural identity of Chinese migrants. My strong personal interest in the field of intercultural and migration studies motivated me to undertake this study. Based on my own experiences as a Chinese migrant woman living in Ireland for nearly eighteen years, I was inspired to explore other Chinese migrant women's cross-cultural experiences in Ireland to see whether they had the same kind of journey as mine. It was fascinating to discover the concerns of Chinese migrant women, and to analyze their intercultural experiences and cultural identity in relation to my personal experience. It could be argued, of course, that my own bias would influence the research - I feel, however, that it gave me some empathy for the participants, and allowed them to be more open in their answers 
to the questionnaires during the interviews. It is hoped this research will provide an original insight into the identity development of Chinese migrant women living in Ireland.

\section{Theoretical Approaches to the Study of Migration}

The situations and conditions that influence migration are generally tested in terms of push and pull factors. ${ }^{10}$ Push and pull factors are those factors which either forcefully 'push' people into migration or attract them. Push factors are negative factors tending to force migrants to leave origin countries, while pull factors are positive factors attracting migrant to go to destination countries in the expectation of improving their standard of living. According to Kofman, women migrate for a diversity of motivations, including better economic opportunities, to achieve a greater degree of independence, to escape patriarchal oppression, or women's increasing participation in higher education. ${ }^{11}$ Breton is generally credited with introducing the concept of institutional completeness to explore how migrants integrated in host societies. ${ }^{12}$ According to Breton's research conducted in the United States: 'Many (ethnic communities) have developed a (...) formal structure and contain organizations of various sorts: religious, educational, political, recreational, national, and professional. Some have organized welfare and mutual aid societies. Some operate their own radio station or publish their own newspapers and periodicals. The community may also sustain a number of commercial and services organizations. Finally, it may have its own churches and sometimes its own schools.' 13 Researchers have investigated the relationships between institutional completeness and acculturation strategies. Ward and Kennedy suggest that migrants may be discouraged from participating in the host society due to a high level of institutional completeness. ${ }^{14}$ Immigration communities with high levels of institutional completeness are more likely to allow the separation strategy to prevail and have the potential to cause acculturative stress. Portes and 
Rumbaut argue that migrants can soften 'their landing' in the host country by using existing social networks and organizations. ${ }^{15}$

\section{Theoretical Approaches to the Study of Ethnic Identity}

According to Phinney, ethnic identity revolves around the knowledge an individual obtains from participation in a social group regarding his or her membership of that group, manifested as a component of self-concept. ${ }^{16}$ This membership offers the individual both emotional support and values. Phinney highlights that ethnic identity consists of the following components: ethnic self-identification in terms of membership of a group, participation in and commitment to the group, possessing both positive and negative attitudes towards the group, a feeling of common attitudes and values, and the practicing of ethnic and cultural traditions. ${ }^{17}$ Self-identification refers to the self-assignment of an ethnic label. Phinney states that the attitude concerning an individual's group membership can affect their ethnic identity. ${ }^{18}$ It is commonly accepted that ethnic identity is reinforced by positive attitudes and contentment with a person's own ethnic group. Negative attitudes towards a person's own ethnic group could lead to a denial of one's ethnic identity. The components frequently used to evaluate ethnic involvements are language, friendship, social organizations, religion, cultural traditions and politics. Fishman points out that language is one of the most significant markers of ethnic identification. ${ }^{19}$ Chow echoes that language can be considered a core aspect of identity and culture. Social Identity Theory states that membership of a group offers individuals a sense of belonging that enhances a positive self-concept. ${ }^{20}$ It was Lewin who first emphasized how critical the ability to identify with a group was to maintain a sense of well-being, thus establishing the importance of social identity. ${ }^{21}$ Tajfel and Turner argue that the mental health and stability of ethnic group members is reliant on a sense of group identity. ${ }^{22}$ As ethnic group members value their ethnic group and extract self-esteem from their sense of belonging, therefore ethnic identification may play an important role in the self-concept. Yamada and 
Singelis declare that ethnic identity can be affected by contact with another ethnic group. ${ }^{23}$ Scholars in the field of intercultural studies have discussed the changing identities that include both the home and host culture and that result from cross-cultural contact. Kim points out that hybridization of identity emerges from the simultaneous engagement in both the home culture and the host culture, which resembles the development of a larger intercultural identity as a result of engaging in the process of cross-cultural adaptation. ${ }^{24}$ Petkova declares that most sojourners have developed a hybrid identity in the process of cross-cultural adaptation although they struggle to confirm their identity. ${ }^{25}$

\section{Theoretical Approaches to the Study of Cross-Cultural Adaptation}

It was Oberg who defined the distress that the sojourner experienced as a result of losing all familiar indications, signs and symbols from their physical and social environment as "culture shock". ${ }^{26}$ Furham and Bochner finds that symptoms known to arise from culture shock are feelings of a loss of importance, confusion, anxiety, depression and feelings of stress. ${ }^{27}$ Berry listed four strategies of acculturation: assimilation, integration, separation and marginalization. ${ }^{28}$ Gudykunst introduces the Anxiety/Uncertainty Management (AUM) model which states that cross-cultural adaptation is a method of uncertainty reduction. Culture shock is a product of uncertainty, in order to reduce uncertainty and adapt effectively, migrants must have a solid sense of self-awareness, adaptive attitudes and behavior and high tolerance for ambiguity. ${ }^{29}$ According to Kim, the concept of cross-cultural adaptation has a broader definition than most similar concepts, such as acculturation, adjustment, coping/adjustment, and integration. Kim describes the adaptive personality as: openness; strength; positivity. The adaptive personality immensely aids the process of cross-cultural adaptation for migrants. ${ }^{30}$ Kim's integrative theory of cross-cultural adaptation appears to be the dominant theory among the theories related to cross-cultural adaptation. Utilizing a wide range of factors such as 
communication, psychological and sociological research, the aim of the theory is to enhance understanding of the processes of cross-cultural adaptation. ${ }^{31}$

\section{Research methodology}

The empirical work for the current research was informed by a qualitative approach based on thematic analysis. In-depth, semi-structured interviews were conducted with a view to capturing narratives of Chinese migrant women's identity. A total of twelve Chinese women were chosen to participate in my interviews. The participants come from different provinces and cities in China. All the participants have lived in Ireland for more than five years. Their ages range from twenty to mid-fifties. The participants were selected partly because of availability and partly because of their visa status.

- The first group is those who hold a student visa (Stamp 2). There are six women in this group.

- The second group is those who hold a dependent visa (Stamp 3). There are four women in this group and they are the spouses of migrants who hold work permits or long-term residency.

- The third group is those who hold stamp 4. There are two women in this group. They obtain long-term residence in Ireland because they gave birth to Irish-born children. 
Table 3.1 Profiles of Research Participants

\begin{tabular}{|c|c|c|c|c|c|}
\hline Interviewees & \begin{tabular}{|l|} 
Age, marital \\
status \\
and children
\end{tabular} & $\begin{array}{l}\text { Reasons } \\
\text { for coming to } \\
\text { Ireland }\end{array}$ & $\begin{array}{l}\text { Prior cross- } \\
\text { cultural } \\
\text { experiences }\end{array}$ & visa status & $\begin{array}{l}\text { Level of } \\
\text { English }\end{array}$ \\
\hline Interviewee 1 & $\begin{array}{l}29, \quad \text { single, no } \\
\text { children. }\end{array}$ & Study & None & Stamp 2 & Basic \\
\hline Interviewee 2 & $\begin{array}{l}\text { 41, married with } \\
\text { one child. }\end{array}$ & Study & \begin{tabular}{|l} 
Traveled \\
Thailand, \\
Singapore and \\
Malaysia for short \\
periods
\end{tabular} & Stamp 2 & $\begin{array}{l}\text { Inter- } \\
\text { mediate }\end{array}$ \\
\hline Interviewee 3 & $\begin{array}{l}27, \quad \text { single, no } \\
\text { children. }\end{array}$ & Study & $\begin{array}{l}\text { Studied in Finland } \\
\text { for one year }\end{array}$ & Stamp 2 & advanced \\
\hline Interviewee 4 & $\begin{array}{l}20, \quad \text { single, } \\
\text { children. }\end{array}$ & $\begin{array}{l}\text { Family } \\
\text { unification }\end{array}$ & \begin{tabular}{|l|l} 
None &
\end{tabular} & Stamp 3 & Basic \\
\hline Interviewee 5 & $\begin{array}{l}39, \text { married } \\
\text { with one Irish-born } \\
\text { child }\end{array}$ & $\begin{array}{l}\text { Family } \\
\text { unification }\end{array}$ & None & Stamp 3 & No English \\
\hline Interviewee 6 & $\begin{array}{l}55, \text { married with } \\
\text { one child. }\end{array}$ & $\begin{array}{l}\text { Family } \\
\text { unification }\end{array}$ & None & Stamp 3 & No English \\
\hline Interviewee 7 & \begin{tabular}{|l|}
30, married \\
with two \\
Irish-born \\
children.
\end{tabular} & Study & None & Stamp 4 & $\begin{array}{l}\text { Inter- } \\
\text { mediate }\end{array}$ \\
\hline Interviewee 8 & $\begin{array}{l}\text { 26, married, no } \\
\text { children. }\end{array}$ & Study & None & Stamp 2 & $\begin{array}{l}\text { Inter- } \\
\text { mediate }\end{array}$ \\
\hline \begin{tabular}{|l|} 
Interviewee 9 \\
\end{tabular} & \begin{tabular}{|l|}
42, married \\
with one \\
Irish-born child. \\
\end{tabular} & Visit her sister & $\begin{array}{|lrr|}\text { Studied } & & \text { in } \\
\text { Moscow } & \text { for } & \text { one } \\
\text { year } & & \\
\end{array}$ & Stamp 4 & $\begin{array}{l}\text { Inter- } \\
\text { mediate }\end{array}$ \\
\hline $\begin{array}{l}\text { Interviewee } \\
10\end{array}$ & $\begin{array}{l}\text { 27, married, no } \\
\text { children. }\end{array}$ & Study & None & Stamp 2 & advanced \\
\hline $\begin{array}{l}\text { Interviewee } \\
11\end{array}$ & $\begin{array}{l}35, \text { single, no } \\
\text { children. }\end{array}$ & Study & None & Stamp 2 & $\begin{array}{l}\text { Inter- } \\
\text { mediate }\end{array}$ \\
\hline $\begin{array}{l}\text { Interviewee } \\
12\end{array}$ & $\begin{array}{l}\text { 47, married with } \\
\text { two children. }\end{array}$ & $\begin{array}{l}\text { Family } \\
\text { unification }\end{array}$ & None & Stamp 3 & No English \\
\hline
\end{tabular}


The interviews were conducted in Mandarin Chinese because the participants would feel more comfortable when interviewed in their mother tongue by a co-ethnic interviewer, and therefore the validity of the research would increase. Braun and Clarke state that it is essential for verbal data such as interviews to be transcribed to written form in order to conduct a thematic analysis. ${ }^{32}$ The interview data of the current research was transcribed to Chinese and then translated into English. I present data from three themes, derived from the interviews, identified as facilitators of or hindrances to the cross-cultural adaptation of Chinese women. In presenting these themes, I have provided detailed descriptions of their narratives to give voices to these Chinese women immigrants. I believe that the use of thick descriptions can be more trustworthy and credible than statistics because thick description facilitates a deeper understanding of the significance of Chinese women's cross-cultural experiences.

\section{Findings and discussion}

Based on an analysis of Chinese women's cross-cultural adaptation experience in Ireland, this study identifies seven facilitators of the cross-cultural adaptation of the Chinese migrant women: motivation; prior cross-cultural experiences; preparation; perceived social support; integrative attitude; gender and intercultural personality characteristics. Through exploring the concept of acculturative stress of Chinese migrant women in Ireland, this study identified barriers to the cross-cultural adaptation of Chinese migrant women - cultural distance; visa status and perceived discrimination. This study also suggests that host language (English) proficiency; institutional completeness; age of immigration; length of stay in the host country and using modern technology can be both facilitators of and barriers to cross-cultural adaptation (see table 3.2 below). These facilitating/hindering factors were deemed significant based on the frequency to reference to them and on the importance which the women attributed to them during the interviews. 
Table 3.2 Facilitators and barriers to cross-cultural adaptation identified in the current study

Facilitators and Barriers to Cross-Cultural Adaptation Identified in the Current Study

\begin{tabular}{|c|c|}
\hline Facilitators & Hindrances \\
\hline $\begin{array}{l}\text { - } \text { Motivation } \\
\text { - Prior cross-cultural experience } \\
\text { - Preparation } \\
\text { serceived social support from two } \\
\text { society: Chinese networks and the host } \\
\text { - Integrative attitude } \\
\text { - Gender } \\
\text { - Personality characteristics: openness; } \\
\text { self-esteem and self-efficacy }\end{array}$ & $\begin{array}{ll}\text { - } & \text { Cultural distance } \\
\text { - } & \text { Visa status } \\
\text { - } & \text { Perceived discrimination }\end{array}$ \\
\hline \multicolumn{2}{|c|}{ Facilitators / Hindrances } \\
\hline \multicolumn{2}{|c|}{$\begin{array}{l}\text { Host language proficiency; institutional completeness; length of stay in the host country; age } \\
\text { and using modern technology can be both facilitators of and barriers to cross-cultural } \\
\text { adaptation }\end{array}$} \\
\hline
\end{tabular}

\section{Factors which Facilitate Cross-Cultural Adaptation}

Chinese women in the current study are highly motivated to come to Ireland for a better life, such as for family reunification or further education. Education is valued and prioritized in Confucian beliefs. Chinese parents highly value education and want to give their children the best they can for their education. Some women in this study mentioned that they were the only child in the family. The 'One child policy' in China, where families are allowed only one child, resulted in parents devoting themselves to their only child, with little regard to cost or effort. Their parents decided to send them abroad to study and paid their tuition fees because they believed that studying abroad offered better opportunities to their children. With the growth 
and emergence of China as a major world player, English has become so important in China now. As an international language, English is the language of business, technology, sport, and aviation in China. Chinese migrants believe that they can find a better job in China with better English language skills and they chose to come to Ireland specifically to improve their English language skills, either through English language school courses or through communication with native speakers in an English-speaking environment in Ireland. Although dependent on personal circumstances, the majority of women in this study saw coming to Ireland as an opportunity to escape family strictness and enjoy independence, adventure and self-fulfillment. These women's motivations are largely "pull” factors rather than "push" factors. As a result, they had a more open and positive attitude towards Irish culture on arrival, which in turn facilitated their cross-cultural adaptation.

Most women in this study had no prior cross-cultural experience; however, those who had prior cross-cultural experience highlighted that their prior cross-cultural experience assisted them in managing their life in Ireland, particularly in the early stages of migration. Chinese women in this study put a lot of effort into preparing themselves before they started their journey of migration to Ireland so they can adjust to an unfamiliar environment in the host country. The preparation includes gathering information about life in Ireland from friends or family members in Ireland and from the education agents in China; improving English language skills in order to be able to survive in the new country. Pre-arrival information gathering facilitates an individual's adaptation to the host culture on arrival because it creates reasonable expectations for the individual which can help reduce uncertainty and anxiety which in turn facilitate adaptation.

Chinese women in this study received social support from two sources: existing Chinese networks both in China and Ireland, and host-culture networks. Chinese women in this study stated that they made friends with Irish people such as their neighbors, landlords and 
workmates. They set up their new social networks in Ireland and gained support from within the host community. Overcoming the language barrier is crucial to creating these social networks. They illustrated the importance of a high-level of English, which allowed them to deepen their friendship with Irish people. Chinese women in this study acknowledge that they have received practical support from Irish society and social support facilitates their crosscultural adaptation. Some governmental and non-governmental organizations provide help for Chinese migrants including free consultations and Chinese interpreting services. Chinese women in the current research indicated their use of these services in Ireland.

Chinese women in this study agreed that having an open personality made it easier to adjust to life in Ireland. This study found that women who have high levels of efficacy adapted to life in Ireland better and were more satisfied with life because they tended to regard setbacks encountered during the process of adaptation as challenges rather than difficulties. Chinese women in this study believe it is easier for women to adapt to the life in Ireland because women enjoy a relatively equal status to men and women are respected in Ireland.

\section{Factors which Hinder Cross-Cultural Adaptation}

Through reviewing the concept of acculturative stress of Chinese women immigrants in Ireland, this study identified three factors which hinder the cross-cultural adaptation of Chinese migrant women - cultural distance; visa status and perceived discrimination.

In the current study, cultural distance is an important factor which made Chinese migrant women's process of cross-cultural adaptation more difficult. Irish culture is very different from Chinese culture. For example, throughout the data English language acquisition is seen as one of the biggest challenges that Chinese women migrants encounter. Chinese women in this study drew comparisons between Chinese and Irish drinking cultures. They complained about 
extensive alcohol drinking in Irish culture. This perception caused them to develop negative attitudes towards Irish culture which in turn stunts their adaptation.

Chinese women in this study felt structurally discriminated against within the migration system in Ireland because they do not have the same freedom to apply for full-time jobs as member from other European Union countries. The majority of women in this study work in the unskilled sector, for example: restaurants, pubs or cleaning companies because they have less opportunity to enter the labor market. Chinese women's adaptation was hindered because they have less opportunity to enter the labor market to achieve their personal goals and objectives. They feel they are losing out in the competition with other European migrants because they are structurally disadvantaged. This structural disadvantage in turn hinders their adaptation to the host culture, as they struggle to access the opportunities which are available to other European migrants who are not bound by visa restrictions. This is very difficult for individual migrants to change, no matter they how motivated they are, as the power to change such restrictions resides with government authorities.

Chinese women in this study mentioned being subjected to discrimination both in work and on the streets. They reported that they experienced racial harassment and abuse from youths and teenagers on streets because they are a "visible" minority in Ireland. This perception of discrimination actually hindered Chinese women's adaptation because it caused them to develop negative attitudes towards Irish culture which in turn stunts their adaptation because it reduces the amount of contact with the host community and culture. Chinese students coming to Ireland had limited support in dealing with immigration and other services, although they have paid big tuition fees. Experiences of renewing visas in immigration offices were unpleasant and often created stress and anxiety, thus making their process of adaptation more difficult. Chinese women in this study stated that they felt discriminated against in the work place. Some of them think that they have less opportunity of promotion than EU staff; some of 
them were paid less and had to work longer, more unsociable hours. As well as this, it was felt that their career paths were being impeded by prejudiced management who favored staff from within the European Union. The negative feelings that Chinese migrant women associate with these events individually affect their individual cross-cultural adaptation as these negative experiences cause feelings of rejection and prevent them from participating in the host culture.

\section{Factors that can be both Facilitators of and Barriers to Cross-Cultural Adaptation}

This study suggests that host language (English) proficiency; institutional completeness; age; length of stay in the host country; using of media and modern technology can be both facilitators of and barriers to cross-cultural adaptation. Good English skills can facilitate communication with the host nationals and use of mass host media; a poor level of English is perceived as a barrier for Chinese women migrants to integrate into the host society. Institutional completeness offers a way to make a transition from the migrant women's own culture into the new culture; high levels of institutional completeness hinder communication with the host society. Women who migrated at a younger age found it was easier to adapt to the host society; while women who migrated at an older age found it more difficult to adjust. Migrants experience different levels of stress at different times of their residency in the host country. The period of arrival is a critical phase in which migrants experience physical, social and cultural changes or losses. Uncertainty is at its highest level at the initial stage and reduces gradually with time. Using modern technology can be helpful to diminish homesickness; but it has potential to keep migrants away from people of the host culture.

\section{Development of Intercultural Identity}

The current study suggests that migration creates a space for personal maturity, which leads to development of a larger intercultural identity, in addition to the material benefits gained from 
migrating to Ireland. Successful adaptation results in an intercultural identity. Chinese women in this study openly appreciates both their own home culture and the new host culture. An intercultural identity was developed, integrating aspects of both Chinese and Irish culture:

Interviewee 1: I feel that I am becoming international. I benefit from my traditional Chinese culture so I hope that I can keep it. Meanwhile, I have absorbed western culture and I will keep learning it. I feel that I have enhanced my abilities in Ireland. First, my English has improved. Second, I learned to think independently and make decisions on my own. I was childish and impulsive when I was in China but now I handle matters with discretion. I was pampered and indulged since childhood but now I do things conscientiously and reliably. I also made more money than in China. I am very content with my life.

Interviewee 2: I like reading the Buddhism book "Xinyu". It is about the enlightenment of life and guidance of people's behavior. I worship Buddhism. I like Chinese traditional culture. I decorated my room in a Chinese style using Chinese knots and Chinese paper-cutting. My friends were fascinated when they came to visit my house. I cook Chinese food for them. I like reading Chinese classical poems. I participated in a Chinese poem competition on the internet. I also like reading English novels and English magazines. I often listen to BBC news, especially reports about China and financial news. I would love to get to know more about Western culture and introduce Chinese culture to Irish people.

Most Chinese women have an English name and they use their English names at the early stage of migration as a sign of assimilation. However, they think that their Chinese name is part of the cultural identity which was given by their parents and they keep their Chinese names in their later stage of migration. This is a strong signal of their pride in their culture and their ancestry. 
Interviewee 3: I have an English name. I used my English name when I first came to Ireland until I met a friend in Ireland. He told me that my Chinese name is pleasant to the ears and he asked me why I gave it up. He advised me to keep my own cultural identity. His words woke me up. My name was given to me by my parents and I should respect my parents. Actually my Chinese name is easy to remember. So I started to use my Chinese name. Now my colleagues still call my English name because they are used to it. But the friends I met later call me by my Chinese name.

Interviewee 8: An English name is more easily accepted by Irish people because my English name is easier for my classmates to pronounce. But Ifeel that my English name does not belong to me. Sometimes I don't even know it is me when other people call my English name. So I think it is better to tell other people my Chinese name. At least it is my real name.

Chinese women express pride in their Chinese culture and traditions, including Chinese food culture. They are proud of being Chinese because the reputation and importance of China in the West has been growing steadily. They refer to the increased status of China on the international scene and deprive pride from it.

Interviewee 4: I am very proud of being Chinese because China is becoming stronger. One of my Chinese friends has an Irish boyfriend. His mother looked down upon my friend because she thought Chinese people were very poor. Some short-sighted Irish didn't know that China has developed fast over the last few years. I am proud that China is becoming one of the strongest countries in the world. Now more and more Irish people go to China for travelling and they get to know China better than before.

Self-esteem helped Chinese women feel accepted by the people in the host society; thus they could easily adapt to life in Ireland. Chinese women who gain an understanding of the social 
norms, attitudes and behaviors in the host country feel closer to the host culture. This in turn give them self-confidence to bring their own culture to the attention of Irish people and feel proud of playing the role of an intercultural ambassador. They want to maintain their Chinese cultural identity and heritage, at the same time they are committed to developing relationships with Irish mainstream society.

Interviewee 10: I shared the Chinese culture with my Irish friends. I showed Chinese knots and ornaments of the Chinese zodiac to my friends. I also explained the meaning of the Chinese zodiac to my friends and they were amazed. ...I like eating Chinese food and cooking Chinese food. My Irish friends and neighbors like eating the food I cooked for them. I introduce Chinese food to them and recommend Chinese supermarkets to them so they can buy Chinese food. They got recipes from me and learned to cook Chinese food. I am very happy that I can have a big influence on them.

\section{Conclusion}

This research presents an original qualitative study on the cross-cultural adaptation process and identity reconstruction of Chinese migrant women in Ireland. The research findings emphasized the difficult nature of cross-cultural adaptation. Chinese women come to Ireland with deeply engrained traditions, such as a strong work ethic and desire for education. Their experiences tell us that no matter how prepared or motivated they are, there are setbacks, such as language barriers and perceived discrimination which hinder their cross-cultural adaptation and therefore complicate their sense of belonging in Irish society. Overall, most women in this study are positive about their experiences of living in Ireland. They believe these experiences broadened their mind and they became more independent and mature. The research findings suggest that migration creates a space for personal maturity, which leads to development of a larger intercultural identity. Successful adaptation results in an intercultural identity. 
This study aims to make a worthwhile contribution to the field of research of identitydevelopment and cross-cultural adaptation of female migrants. Firstly, the experiences of Chinese female migrants in an Irish host society were not studied in particular before. It is therefore useful for this research to do so. As Irish culture and society are becoming increasingly diverse, it is legitimate and useful for this study to analyze one element of Irish diversity - Chinese female migrants - as one component of contemporary Ireland. Secondly, the individual experiences and perceptions of Chinese migrant women need to be explored, as they are constantly changing along with Irish society and research is rapidly rendered obsolete. A limitation of this study is the size of the sampling. Using a qualitative research framework, this study has reported on the Chinese women's self-reported opinions and perspectives, which may not be entirely reflective of the experiences of other migrants groups. The size of the sampling is small and not generalizable. It does not address the social context; it is one small snapshot in time. Future studies would necessitate further investigations of similar topics with different population groups and with larger and more random samples including Chinese male migrants and undocumented migrants.

\section{Bibliography}

Berry, John. 1997. Immigration, Acculturation, and Adaptation. Applied Psychology: An International Review, (1997). 46, 5-34.

Braun, Virginia and Clarke, Victoria. Using Thematic Analysis in Psychology. Qualitative Research in Psychology. (2006). 3, 77-101.

Breton, Raymond. Institutional Completeness of Ethnic Communities and the Personal Relations of Immigrants. The American Journal of Sociology, (1964), 70 (2): 193-205.

Castles, Stephen and Miller, Mark J. The Age of Migration: International Population Movements in the Modern World. Basingstoke: Palgrave. 2003. 
Central Statistics Office, Census: Non-Irish Nationals Living in Ireland. Cork: Central Statistics Office. 2007.

Central Statistics Office, Census: Principal Demographic Results, Dublin, Stationery Office. 2008

Chow, Henry, 2001. The Challenge of Diversity: Ethnic Identity Maintenance and Heritage Language Retention in the Canadian Mosaic. Commissioned by the Department of Canadian Heritage for the Ethnocultural, Racial, Religious, and Linguistic Diversity and Identity Seminar, Halifax, Nova Scotia, November 1-2, 2001.

Fishman, Joshua A. Language and Ethnicity. In: Language and Ethnicity, and Intergroup Relations. Edited by Howard Giles, London: Academic Press. 1977.

Furham, Adrian and Bochner, Stephen. Culture Shock: Psychological Reactions to Unfamiliar Environments. New York: Methuen. 1986.

Gudykunst, William B. An Anxiety / Uncertainty Management (AUM) Theory of Strangers' Intercultural Adjustment. Theorizing about Intercultural Communication. Thousand Oaks, CA: Sage. 2005.

Hall, Stuart. "Cultural Identity and Diaspora”. In: Theorizing Diaspora, edited by Jana Evans Braziel and Anita Mannur. U. S. A.: Blackwell Publishing. 2003.

Heine, Steven J., Lehman, Darrin R., Markus, Hazel Rose and Kitayama, Shinobu. "Is there a Universal Need for Positive Self-Regard?”Psychological Review, (1999). 106, 766-794.

Kim, Young Yun. "Inquiry in Intercultural and Development Communication". Journal of Intercultural Communication Research. 55(3), 2005. 554-577.

Kim Young Yun. Becoming Intercultural. Thousand Oaks: Sage Publications. 2001. 
Kim Young Yun. Communication and Cross-cultural Adaptation. London: Multilingual Matters. 1988.

Kofman Eleonore. Female "Birds of Passage" A Decade Later: Gender and Immigration in the European Union. International Migration Review, (1999). 33, 269-299.

Krings, Torben. "The impact of the economic crisis on migrants and migration policy: Ireland" in Migration and the Economic Crisis: Implications for Policy in the European Union. Geneva: International Organization for Migration. 2010.

Markus, Hazel Rose and Kitayama, Shinobu. "Culture and the Self: Implications for Cognition, Emotion, and Motivation”. Psychological Review, (1991). 98, 224-253.

Oberg, Kalervo. Culture Shock and the Problems of Adjustment to New Cultural Environment. Edited Talk, Washington, Foreign Service Institute. 1958.

Petkova, Diana. Culture Shock and Adaptation in a Multiethnic City. Paper presented at the Third Conference "Diversity in Cities: Visible and invisible walls" December 2007. The Fondazione Eni Enrico $\quad$ Mattei $\quad$ Series http://www.feem.it/Feem/Pub/Publications/EURODIVPapers/default.htm

Phinney, Jean S., Horenczyk, Gabriel, Liebkind, Karmela and Vedder, Paul. "Ethnic Identity, Immigration, and Well-being: An Interactional Perspective”. Journal of Social Issues, (2001). Vol. 57 (3), 493-510.

Phinney, Jean S. The Multigroup Ethnic Identity Measure: A New Scale for Use with Diverse Groups. Journal of Early Adolescence, (1992). 7. 156-176.

Phinney, Jean S. Ethnic Identity in Adolescents and Adults. Psychological Bulletin. (1990). $108(3), 499-514$.

Portes, Alejandro and Rumbaut, Ruben G. Immigrant America: A Portrait. $3^{\text {rd }}$ Ed. (Berkeley, CA: University of California Press. 2006.) 
Ruhs, Martin. Managing the Immigration and Employment of Non-EU Nationals in Ireland. Studies in Social Policy, (2005), 19, 1-152

Tajfel, Henri and Turner, John, C. The Social Identity Theory of Intergroup Behavior. In: Psychology of Intergroup Relations. Edited by Worchel, S. and Austin, W. Nelson-Hall, Chicago, 1986. 7-24.

Ting-Toomey, Stella. "Ethnic Identity and Close Friendship in Chinese-American College Students”. International Journal of Intercultural Relations, (1981). 5, 383-406.

Tsai, Jeanne L., Ying, Yu-Wen and Lee, Peter Allen. "Cultural Predictors of Self-esteem: A Study of Chinese American Female and Male Young Adults”. Journal of Cultural Diversity and Ethnic Minority Psychology. (2001). 7, 284-297

Wang, Yin Yun. The Chinese Earthquake Appeal Network in Ireland. Migrant Networks Project, Trinity Immigration Initiative. 2008.

Ward, Colleen and Kennedy, Antony 'Acculturation Strategies, Psychological Adjustment, and Sociocultural Competence during Cross-cultural Transitions'. International Journal of Intercultural Relations, no. 18 (1994), 329-343.

Yamada, Ann-Marie and Singelis, Theodore, M. Biculturalism and Self-construal. International Journal of Intercultural Relations, (1999). 23, 697-709.

Yau, Nicola “Celtic Tiger, Hidden Dragon: Exploring Identity among Second Generation Chinese in Ireland". Translocation. (2007). Volume 2. Issue I. 48-69.

\section{Notes}

\footnotetext{
${ }^{1}$ Young Yun Kim, Becoming Intercultural (Thousand Oaks: Sage Publications. 2001).
} 
${ }^{2}$ Torben Krings, 'The impact of the economic crisis on migrants and migration policy: Ireland,' in Migration and the Economic Crisis: Implications for Policy in the European Union (Geneva: International Organization for Migration. 2010).

${ }^{3}$ Martin Ruhs, 'Managing the Immigration and Employment of Non-EU Nationals in Ireland,' Studies in Social Policy, no. 19 (2005): 1-152

${ }^{4}$ Central Statistics Office, Census: Non-Irish Nationals Living in Ireland. Cork: Central Statistics Office. 2007.

${ }^{5}$ Ruhs, 'Managing the Immigration and Employment of Non-EU Nationals in Ireland.'

${ }^{6}$ Nicola Yau, 'Celtic Tiger, Hidden Dragon: Exploring Identity among Second Generation Chinese in Ireland,' Translocation 2, no. 1 (2007): 48-69, 49.

${ }^{7}$ Wang, Yin Yun. The Chinese Earthquake Appeal Network in Ireland. Migrant Networks Project, Trinity Immigration Initiative. 2008.

${ }^{8}$ Central Statistics Office, Census: Principal Demographic Results, Dublin, Stationery Office. 2008 .

9 'Who we are. A supplement to the Irish Times,' Irish Times, Dublin, May 23, 2006.

${ }^{10}$ Eleonore Kofman, 'Female "Birds of Passage" A Decade Later: Gender and Immigration in the European Union,' International Migration Review 33, no. 2 (1999): 269-299; Stephen Castles and Mark J. Miller, The Age of Migration: International Population Movements in the Modern World (Basingstoke: Palgrave. 2003).

${ }^{11}$ Kofman, "Female "Birds of Passage" A Decade Later: Gender and Immigration in the European Union.'

${ }^{12}$ Raymond Breton, 'Institutional Completeness of Ethnic Communities and the Personal Relations of Immigrants,' The American Journal of Sociology 70, no. 2 (1964): 193-205. 
${ }^{13}$ Breton, 'Institutional Completeness of Ethnic Communities and the Personal Relations of Immigrants, 194.

${ }^{14}$ Colleen Ward and Antony Kennedy, 'Acculturation Strategies, Psychological Adjustment, and Sociocultural Competence during Cross-cultural Transitions'. International Journal of Intercultural Relations, no. 18 (1994), 329-343.

${ }^{15}$ Alejandro Portes and Ruben G. Rumbaut, Immigrant America: A Portrait. $3^{\text {rd }}$ Ed. (Berkeley, CA: University of California Press. 2006.)

${ }^{16}$ Jean S. Phinney, 'The Multigroup Ethnic Identity Measure: A New Scale for Use with Diverse Groups,' Journal of Early Adolescence, no. 7 (1992): 156-176.

${ }^{17}$ Jean S. Phinney, 'Ethnic Identity in Adolescents and Adults,' Psychological Bulletin 108, no. 3 (1990): 499-514.

${ }^{18}$ Phinney, 'Ethnic Identity in Adolescents and Adults,' Psychological Bulletin 108, no. 3 (1990): 499-514.

${ }^{19}$ Joshua A. Fishman, 'Language and Ethnicity,' in Language and Ethnicity, and Intergroup Relations. Edited by Howard Giles (London: Academic Press. 1977).

${ }^{20}$ Henry Chow, The Challenge of Diversity: Ethnic Identity Maintenance and Heritage Language Retention in the Canadian Mosaic, Commissioned by the Department of Canadian Heritage for the Ethnocultural, Racial, Religious, and Linguistic Diversity and Identity Seminar, Halifax, Nova Scotia, November 1-2, (2001), 4.

${ }^{21}$ Lewin, Kurt. Resolving Social Conflict (New York: Harper. 1948). 
${ }^{22}$ Henri Tajfel and John, C. Turner, 'The Social Identity Theory of Intergroup Behavior,' in: Psychology of Intergroup Relations, Worchel, S. and Austin, W. Nelson-Hall, ed. (Chicago: Nelson-Hall Publishers, 1986), 7-24.

${ }^{23}$ Ann-Marie Yamada and Theodore, M. Singelis, 'Biculturalism and Self-construal,' International Journal of Intercultural Relations, no. 23 (1999): 697-709.

${ }^{24}$ Kim, Becoming Intercultural (Thousand Oaks: Sage Publications. 2001).

${ }^{25}$ Diana Petkova, Culture Shock and Adaptation in a Multiethnic City. Paper presented at the Third Conference "Diversity in Cities: Visible and invisible walls" December 2007. The Fondazione Eni $\quad$ Enrico $\quad$ Mattei $\quad$ Series http://www.feem.it/Feem/Pub/Publications/EURODIVPapers/default.htm

${ }^{26}$ Kalervo Oberg, Culture Shock and the Problems of Adjustment to New Cultural Environment. Edited Talk, Washington, Foreign Service Institute. 1958.

27 Adrian Furham, and Stephen Bochner, Culture Shock: Psychological Reactions to Unfamiliar Environments. New York: Methuen. 1986.

28 John Berry, Immigration, Acculturation, and Adaptation. Applied Psychology: An International Review, No. 46 (1997). 5-34.

${ }^{29}$ Gudykunst, William B. An Anxiety / Uncertainty Management (AUM) Theory of Strangers' Intercultural Adjustment. Theorizing about Intercultural Communication. (Thousand Oaks: Sage Publications. 2005).

${ }^{30}$ Kim, Becoming Intercultural (Thousand Oaks: Sage Publications. 2001). 
${ }^{31}$ Kim, Becoming Intercultural (Thousand Oaks: Sage Publications. 2001).

${ }^{32}$ Virginia Braun and Victoria Clarke, Using Thematic Analysis in Psychology. Qualitative Research in Psychology. No. 3, (2006). 77-101. 